\title{
The Effect of Learning Module Program on Mothers'Ability to Adapt to New Foods, Feeding Styles, and Self-efficacy to Their Children with Avoidant Restrictive Food Intake Disorder
}

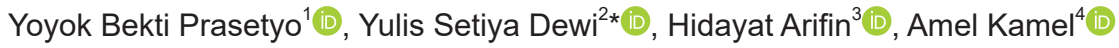 \\ ${ }^{1}$ Department of Community Nursing, Faculty of Health Sciences, University Muhammadiyah of Malang, Malang, Indonesia; \\ ${ }^{2}$ Department of Advanced Nursing, Faculty of Nursing, Universitas Airlangga, Surabaya, Indonesia; ${ }^{3}$ Department of Medical \\ Surgical Nursing, Faculty of Nursing, Universitas Padjadjaran, Bandung, Indonesia; ${ }^{4}$ College of Nursing, King Saud bin Abdul \\ Aziz University, Riyadh, Kingdom of Saudi Arabia
}

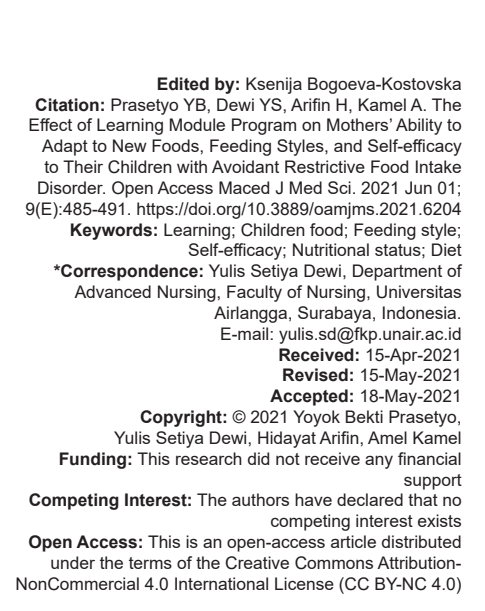

Abstract

BACKGROUND: The education to improve a mother's knowledge is deemed to be important because it may improve children's nutritional status.

AIM: The aim of this study was to examine the effects of learning module program on the mothers' ability to adapt to new foods, feeding styles, and self-efficacy to their children with avoidant restrictive food intake disorder (ARFID)

METHODS: Quasi-experimental design was used to evaluate the effectiveness of learning module program. Fifteen mothers of experimental group were given four meetings within 4 weeks. Each meeting ran about 50 min. Fifteen mothers of control group were conducted home visit and received twice education about the health principals of feeding children. Both experimental group and control group had pre-test and post-test. The data were analyzed using Chi-square test, Fisher's exact test, and Mann-Whitney U-test.

RESULTS: The participants of the experimental group have shown bigger surge of new foods adaptation ( $\mathrm{t}=-2.973$, $p<0.003)$, feeding style $(t=-4.646, p<0.001)$, self-efficacy $(t=-3.652, p=0.001)$ than the control group has.

CONCLUSION: The findings indicated that the learning module program was deemed to be effective to improve mothers' ability to adapt to new foods, feeding styles, and self-efficacy to their children with ARFID.

\section{Introduction}

The children with avoidant restrictive food intake disorder (ARFID) are at high risk of experiencing growth and development disorder [1], [2]. One of the symptoms is difficult to adapt to the new foods [3]. They tend to less consume the variant of foods. The condition impairs the lack of nutritional intake [4]. Lack of variety in food and children's difficulties in adapting to new foods is caused by poor diet and malnutrition [5], [6]. Healthy dietary habit is greatly affected by family factor. In fact, a mother plays an important role in establishing healthy dietary habit to her children. If the mother has poor dietary habit, the children will have the same as well [7]. Mainly, the mother taking care of children with ARFID frequently feels desperate of her children condition. She becomes less confident in solving the problem because she does not have good plan and tends to be apathetic [8], [9]. Finally, the inability of a mother to introduce new foods, to demonstrate healthy food dietary, and to show self-efficacy will severely affect her children's nutritional status.
The prevalence rate of children with eating disorder is reported $35 \%$ [10]. The parent reported that the children under pre-school age with eating new foods problem are between $15 \%$ and $50 \%$ [11]. Meanwhile, feeding style problem is reported $19.3 \%$, authoritarian $14 \%$, and rejection $35.3 \%$ [12]. The prevalence of eating disorders always increases every year in many countries, including in Indonesia [13]. In Malang City, East Java, Indonesia, there are $36.44 \%$ students with eating disorder [14]. The permissive and authoritarian feeding style and rejection in family may impair children's poor dietary habit.

The education to improve a mother's knowledge is deemed to be important because it may increase the children's nutritional status. There is a little research discussing education program delivered to a mother related to children's care with ARFID. The previous research stated that the education of nutritionbased effective community improves dietary habit and children' growth [15]. Another research revealed that the education of nutrition-based effective community 
aimed to optimize children's nutrition in $10001^{\text {st }}$ day of birth improved a mother's intention to actively provide nutritious food [16] and educational program of sensitivity-based effective family improved a mother's perspective to take care of her children [17], [18]. Hence, this study focused on an educational program of nutrition to mothers which were expected to be capable in practicing healthy dietary habit, adapting to new foods to her children, and increasing their self-efficacy to take care of their children with ARFID. The purpose of this study was to analyze the effect of health education program given to a mother toward the improvement of her ability to adapt to new foods, healthy dietary habit, and her self-efficacy to take care of her children.

\section{Methods}

\section{The design of the study}

This study is a quasi-experimental design with two-group with pre-posttest to examine the effect of health education program given to a mother toward the improvement of her ability to adapt to new foods, healthy dietary habit, and her self-efficacy to take care of their children.

\section{Setting and samples}

The population involved in this study was all mothers who take care of their children with ARFID in Malang Regency - Indonesia. The number of samples with $\mathrm{Z}$ in the normal curve for significance level $\alpha$ used in the direct test hypothesis 0.05 was 1.64 . Then, the value of $Z$ with the normal curve used in the direct test hypothesis 0.2 was 1.285 . The standard deviation of the population from other research 0.65 was 15 mothers in the experimental group. Thus, the total samples of 30 mothers consisted of 15 mothers in the experimental group and 15 mothers in the control group (Figure 1).

The inclusion criteria were mothers as a primary caregiver; having literacy skills; and having good physical and mental health. The mothers also had an experience in taking care of under 5 years old children with ARFID symptoms, and eating disorder which affects children's sensory, such as poor perception on food presentation, food smell and taste, in addition children having no chronic disease and congenital disease. Furthermore, the exclusion criteria were mothers who were indirectly taking care of their children (helped by other caregivers).

\section{Ethical considerations}

This study was conducted according to Declaration of Helsinki guidance. The ethical approval

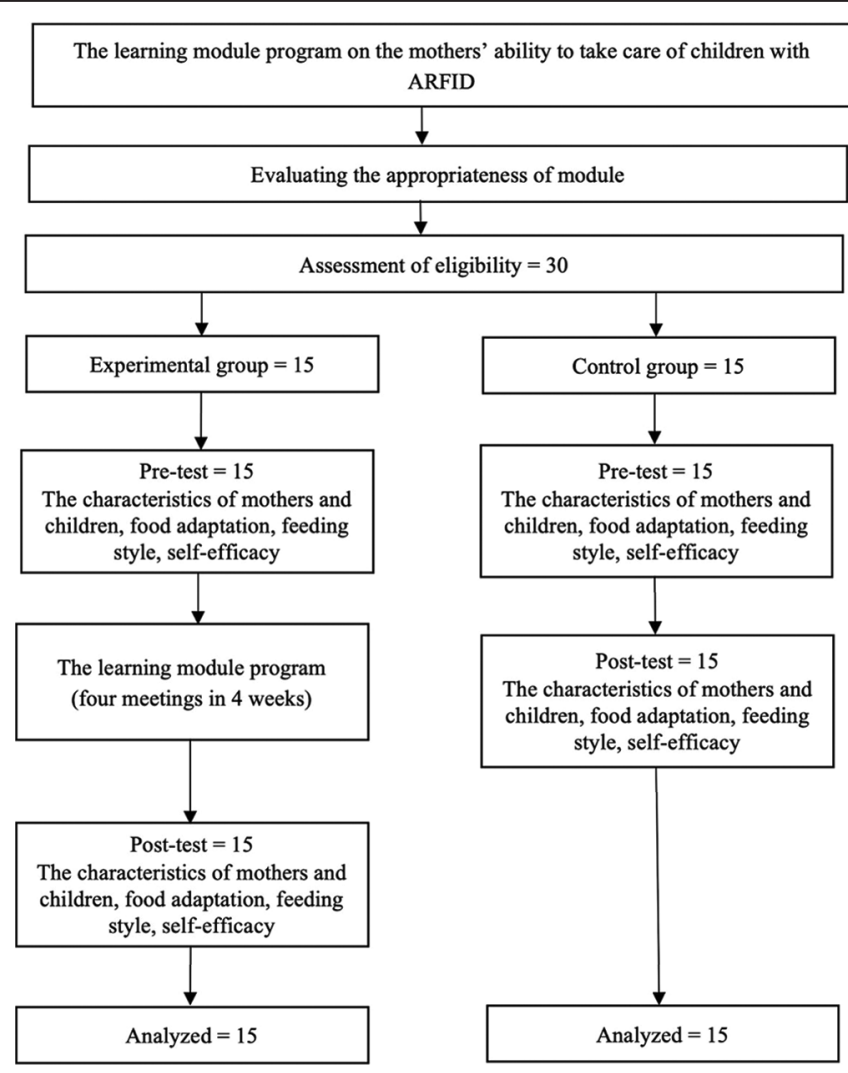

Figure 1: Sample diagram

was issued by the committee of ethics of Faculty of Public Health, Universitas Airlangga number 333-KEPK. All participants were asked to write down the informed consent form and sign it voluntarily after receiving information about the study and their right to participate or not in the study. The researcher convinced that their privacy and confidential information are highly secured.

\section{Measurements}

\section{New foods adaptation}

The questionnaire was used to measure the caregiver's behavior in improving children's social interaction skill and new foods familiarization. It consisted of 8 items ranging from 0 to 8 . The indicators of the questionnaire were (1) social activity stimulus; (2) communication support; (3) new foods availability; (4) feeding practice of new foods; (5) children's engagement in food selection; (6) eating together; (7) letting the children to eat independently; and (8) avoiding new foods at the same time. The Cronbach's alpha value was 0.82 .

\section{Feeding style (practice)}

This questionnaire aimed to evaluate the caregiver's feeding practice toward the children by considering responsive and communication aspects. It 
consisted of 7 items ranging from 0 to 7 . The indicators of the questionnaire were (1) children's motivation to share their own problem; (2) responsive feeding style; (3) developing children's understanding; (4) compliment; (5) good reason; (6) sharing the feelings; and (7) encouraging the children to talk about every action that it has its consequences. The Cronbach's alpha value was 0.84 .

\section{The learning module program}

The design of this study was adjusted by the condition faced by mothers to take care of their children with ARFID. The module was created according to the process of the study at the first stage by identifying the determinant variable of mother's competence. Furthermore, focused group discussion (FGD) was conducted to examine the desire, point of view, need, trust, and experience of mothers in taking care of their children with ARFID. FGD was performed 3 times by involving the mothers, medical staffs, and person in charge of nutritional program at health community center. The content validity of this module had been verified by a nursing professor (judging expert) in a nursing faculty. The specific structure and content of the learning module program are presented in Table 1.

\section{Data collection}

The data were collected in January 2019March 2019 by means of a structured questionnaire

Table 1: Description of intervention

\begin{tabular}{|c|c|c|c|c|}
\hline $\begin{array}{l}\text { Session/ } \\
\text { meeting }\end{array}$ & $\begin{array}{l}\text { Educational } \\
\text { methods }\end{array}$ & Theme & Materials & $\begin{array}{l}\text { Duration } \\
\text { (min) }\end{array}$ \\
\hline 1 & $\begin{array}{l}\text { Face- } \\
\text { to-face } \\
\text { education } \\
\text { session }\end{array}$ & $\begin{array}{l}\text { Father's } \\
\text { proximity } \\
\text { and parental } \\
\text { teamwork to } \\
\text { take care of the } \\
\text { children with } \\
\text { ARFID }\end{array}$ & $\begin{array}{l}\text { 1. Introduction } \\
\text { 2. Education: } \\
\text { a) Father's proximity } \\
\text { (Definition, roles, factors that } \\
\text { influence the father's involvement, } \\
\text { parenting effects of father towards } \\
\text { children development) } \\
\text { b) Parental teamwork } \\
\text { (Definition, the principles of } \\
\text { developing good interaction, } \\
\text { communication techniques) } \\
\text { 3. Question and answer (Q and A) }\end{array}$ & $\begin{array}{l}5 \\
40\end{array}$ \\
\hline 2 & $\begin{array}{l}\text { Face- } \\
\text { to-face } \\
\text { education } \\
\text { session }\end{array}$ & $\begin{array}{l}\text { The } \\
\text { improvement } \\
\text { of children's } \\
\text { adaptation skill } \\
\text { toward eating } \\
\text { new foods }\end{array}$ & $\begin{array}{l}\text { 1. Introduction } \\
\text { 2. Education; } \\
\text { a) Definition of adaptation ability } \\
\text { b) How to improve children's } \\
\text { adaptation ability } \\
\text { c) How to introduce new foods to } \\
\text { the children } \\
\text { 3. Question and answer (Q and A) }\end{array}$ & $\begin{array}{l}5 \\
40\end{array}$ \\
\hline 3 & $\begin{array}{l}\text { Face- } \\
\text { to-face } \\
\text { education } \\
\text { session }\end{array}$ & $\begin{array}{l}\text { Healthy feeding } \\
\text { styles for } \\
\text { children }\end{array}$ & $\begin{array}{l}\text { 1. Introduction } \\
\text { 2. Education: } \\
\text { a) Responsive feeding style } \\
\text { b) Controlling feeding style } \\
\text { c) Indulgent feeding style } \\
\text { d) Neglectful feeding style } \\
\text { 3. Question and answer (Q and A) }\end{array}$ & $\begin{array}{l}5 \\
40\end{array}$ \\
\hline 4 & & & 1. Introduction & 5 \\
\hline $\begin{array}{l}\text { Face-to-fa } \\
\text { The guida } \\
\text { improvem }\end{array}$ & $\begin{array}{l}\text { ace education } \\
\text { ince of self-eff } \\
\text { ent }\end{array}$ & $\begin{array}{l}\text { session } \\
\text { ficacy }\end{array}$ & $\begin{array}{l}\text { 2. Education: } \\
\text { a) Definition } \\
\text { b) The factors that influence } \\
\text { self-efficacy } \\
\text { c) How to improve self-efficacy } \\
\text { 3. Question and answer ( } Q \text { and A) }\end{array}$ & 40 \\
\hline
\end{tabular}

(mothers and children's characteristics, children's adaptation to new foods, feeding style, and selfefficacy). All participants were given the information about the purposes and stages of this study and asked to fill informed consent form. The experimental group was distributed the learning module program and the technical intervention was performed four meetings in 4 weeks. Each meeting had an effective $50 \mathrm{~min}$. The subject matters were about father' involvement (the first meeting), managing eating disorder (the second meeting), promotional behavior (the third meeting), and self-efficacy enhancement (the fourth meeting) delivered by means of PowerPoint visualization and projector display. The control group is performed by home visit in which the group is given health education and learning module in two meetings. The first meeting concerned about health education by presenting the materials with PowerPoint visualization and projector display. Then, the second meeting concerned about the same material as the first one without PowerPoint visualization and projector display. Furthermore, both groups conducted pre- and post-test.

\section{Data analysis}

The data were analyzed using SPSS 22 software (IBM Incorporation, Chicago, IL, USA). The characteristics of mothers and children in the experimental and control groups were analyzed by distributing the frequency, percentage, mean, and standard deviation. The analysis of the characteristics and variables in this study was performed homogeneity test with some related methods, such as Chi-square test, Fisher's exact test, t-test, and the Mann-Whitney U-test. Moreover, Shapiro-Wilk test was applied to verify the variable's normality in a study. The nonnormal distribution of variables was performed using the Mann-Whitney U-test. Meanwhile, the reliability of the instruments (children's ability to adapt, feeding style, and self-efficacy) was analyzed using Cronbach's $\alpha$ parameter. The significance level was considered at $\mathrm{p}<0.05$.

\section{Results}

\section{Homogeneity}

In general, there is no difference between characteristics and variables of the study in the two groups. However, there is a difference between education characteristics and income per month (Tables 2 and 3). 
Table 2: Homogeneity test of the characteristics between the experimental and control groups $(n=30)$

\begin{tabular}{|c|c|c|c|c|c|c|}
\hline \multirow[t]{3}{*}{ Characteristics } & Categories & $\begin{array}{l}\text { Total } \\
(\mathrm{n}=30)\end{array}$ & $\begin{array}{l}\text { Exp. } \\
(n=15)\end{array}$ & $\begin{array}{l}\text { Con. } \\
(n=15)\end{array}$ & \multirow[t]{3}{*}{$\begin{array}{l}x^{2} \\
\text { or } t\end{array}$} & \multirow[t]{3}{*}{$\mathrm{p}$} \\
\hline & & $\mathrm{n}(\%)$ or & $\mathrm{n}(\%)$ or & $\mathrm{n}(\%)$ or & & \\
\hline & & $M \pm S D$ & $M \pm S D$ & $\mathrm{M} \pm \mathrm{SD}$ & & \\
\hline \multirow[t]{4}{*}{$\overline{\text { Age }}$} & Mothers & $31.23 \pm$ & $31.60 \pm$ & $30.87 \pm$ & 0.732 & 0.563 \\
\hline & & 5.72 & 5.53 & 6.07 & & \\
\hline & Children & $2.48 \pm$ & $2.31 \pm$ & $2.64 \pm$ & 0.489 & 0.105 \\
\hline & & 1.27 & 1.03 & 1.49 & & \\
\hline \multirow[t]{3}{*}{ Education levels } & Elementary & $3(10)$ & $0(0)$ & $3(20)$ & 0.040 & 0.000 \\
\hline & $\begin{array}{l}\text { Junior high } \\
\text { school }\end{array}$ & $5(16.7)$ & $1(6.7)$ & $4(26.7)$ & & \\
\hline & $\begin{array}{l}\text { Senior high } \\
\text { school }\end{array}$ & $22(73.3)$ & $\begin{array}{l}14 \\
(93.3)\end{array}$ & $8(53.3)$ & & \\
\hline \multirow[t]{2}{*}{ Status $^{a}$} & Employment & $6(20)$ & $2(13.3)$ & $4(26.7)$ & 0.651 & 0.075 \\
\hline & Unemployment & $24(80)$ & $\begin{array}{l}13 \\
(86.7)\end{array}$ & $11(73.3)$ & & \\
\hline Number of & 1 & $17(56.7)$ & $8(53.3)$ & $9(60)$ & 1.000 & 0.527 \\
\hline \multirow{2}{*}{ children } & 2 & $8(26.7)$ & $5(33.3)$ & $3(20)$ & & \\
\hline & 3 & $5(16.7)$ & $2(13.3)$ & $3(20)$ & & \\
\hline Income per & $<1$ million & $5(16.7)$ & $3(20)$ & $2(13.3)$ & 0.056 & 0.010 \\
\hline \multirow[t]{2}{*}{ month } & 1-2 million & $18(60)$ & $6(40)$ & $12(80)$ & & \\
\hline & $>2$ million & $7(23.3)$ & $6(40)$ & $1(6.7)$ & & \\
\hline \multirow{2}{*}{ Children's gender } & Males & $17(56.7)$ & $9(60)$ & 8 (53.3) & 0.713 & 0.526 \\
\hline & Females & $13(43.3)$ & $6(40)$ & $7(46.7)$ & & \\
\hline
\end{tabular}

Table 3: Homogeneity test of the study variables $(n=30)$

\begin{tabular}{llllll}
\hline Variables & Total $(n=30)$ & Exp. $(n=15)$ & Con. $(n=15)$ & t or Z & $p$ \\
\cline { 2 - 4 } & $\mathrm{M} \pm \mathrm{SD}$ & $\mathrm{M} \pm \mathrm{SD}$ & $\mathrm{M} \pm \mathrm{SD}$ & & \\
\hline Children's adaptation & $5.80 \pm 1.12$ & $6.80 \pm 0.49$ & $4.8 \pm 0.49$ & 0.000 & 1.000 \\
Feeding style & $5.61 \pm 0.79$ & $6.23 \pm 0.49$ & $5.0 \pm 0.50$ & 0.000 & 0.854 \\
Self-efficacy & $3.30 \pm 0.63$ & $3.80 \pm 0.32$ & $2.80 \pm 0.45$ & 0.000 & 0.092 \\
\hline
\end{tabular}

\section{The adaptation to new food}

A mother as a caregiver must comprehend the situation of how to adapt to new foods to the children using the learning module program - the mothers' ability to take care of the children with ARFID. The experimental group experiences more significant progress $(t=-2.973, p<0.003)$ than the control group (Table 4).

\section{Table 4: The adaptation to new food}

\begin{tabular}{|c|c|c|c|c|c|c|}
\hline \multirow[t]{2}{*}{ Variables } & \multirow[t]{2}{*}{ Group } & Pre-test & Post-test & Difference & \multirow[t]{2}{*}{ t or Z } & \multirow[t]{2}{*}{$\mathrm{p}^{\mathrm{a}}$} \\
\hline & & $\mathrm{M} \pm \mathrm{SD}$ & $\mathrm{M} \pm \mathrm{SD}$ & $M \pm S D$ & & \\
\hline $\begin{array}{l}\text { New foods } \\
\text { adaptation }\end{array}$ & $\begin{array}{l}\text { Exp. } \\
\text { Con. }\end{array}$ & $\begin{array}{l}6.13 \pm 0.743 \\
4.57 \pm 0.617\end{array}$ & $\begin{array}{l}7.47 \pm 0.516 \\
4.93 \pm 0.594\end{array}$ & $\begin{array}{l}1.34 \pm 0,227 \\
0.36 \pm 0.023\end{array}$ & -4.735 & $<0.001$ \\
\hline Feeding style & $\begin{array}{l}\text { Exp. } \\
\text { Con. }\end{array}$ & $\begin{array}{l}6.00 \pm 0.655 \\
4.73 \pm 0.458\end{array}$ & $\begin{array}{l}6.47 \pm 0.516 \\
5.27 \pm 0.799\end{array}$ & $\begin{array}{l}0.47 \pm 0.139 \\
0.54 \pm 0.341\end{array}$ & -4.646 & $<0.001$ \\
\hline Self-efficacy & $\begin{array}{l}\text { Exp. } \\
\text { Con. }\end{array}$ & $\begin{array}{l}3.73 \pm 0.458 \\
2.40 \pm 0.632\end{array}$ & $\begin{array}{l}3.87 \pm 0.352 \\
3.20 \pm 0.561\end{array}$ & $\begin{array}{l}0.14 \pm 0.106 \\
0.80 \pm 0.071\end{array}$ & -3.652 & 0.001 \\
\hline
\end{tabular}

\section{Feeding styles}

The understanding of the mother in the experimental group to manage new foods to the children with ARFID using the learning module program is more significant $(t=-4.646, p<0.001)$ than the control group (Table 4).

\section{Self-efficacy}

The mother's self-efficacy to take care of children with ARFID in the experimental group using the learning module program is more significant $(t=-3.652$, $p=0.001$ ) than the control group (Table 4).

\section{Discussion}

This study aims to develop the learning program for mothers to take care of the children with ARFID. The learning module program explains about how to adapt to new foods, to implement healthy dietary habit, and to improve the mother's self-efficacy.

\section{New foods adaptation}

This study discusses about the mother as a caregiver to take care of the children with ARFID and to assist them with new foods consumption. These efforts are indicated by encouraging the children to join social activities, presenting new foods, demonstrating of eating new foods in front of them, involving the children to select the food independently, eating together with family, letting them eat any kind of foods, and avoiding to offer new foods at the same time. Parental readiness in giving new foods based on their age is deemed to be important to prevent neophobia [19]. Presenting examples of new foods, involving children to choose foods, and letting new foods in children are very important for children to adapt to new foods. The children recognize the foods from their appearance, texture, and smell [20]. The frequency of children's exposure to consume new foods is also related to the acceptance of children to new foods [21]. Two important things for parents to do in adapting their children to new foods are social and cognitive environmental factors. Social environmental factors include parental support, pressure during meals, and parental strategies. The cognitive factors affected children's appetites are disgust, texture, appearance, and smell of food [22]. The parents must concern on food presentation because an interesting food display will stimulate children's sensory and motivation to try it on [23]. Parental awareness to adapt their children plays an important factor to increase children's control to respect themselves and others. This is in accordance with the previous study that increasing children's adaptability means increasing children's social skills. Increasing adaptability is a social development for children to play around which allows them to develop their empathy and interact more frequently. It can increase children's awareness to share and be more able to respect themselves and others [24], [25]. In addition, the previous study also showed that new food adaptation will promoted healthy eating and living among refugees and help to reduce health disparities [26].

\section{Feeding styles}

In this study, the ability of caregivers to take care of children with ARFID in adopting a better diet has also increased. This is indicated by behaviors such as encouraging children to convey their problems, 
being responsive to children's feelings and needs, giving compliment, and giving reasons to children why rules must be obeyed. Indeed, the parents will greatly determine children' eating behavior. Children's eating practice is highly determined by the healthy style or diet of the parents [27], [28], [29]. The pattern of proper feeding from infancy will lead to good eating behavior at a later age [11], [30]. Feeding style describes the interaction between parents and children related to the behavior and role of parents in controlling children to eat, such as how much the portion, when the child eats, limiting food, and using food as a gift. Feeding style can be formed from two dimensions, namely, needs and responsiveness. The dimension of the demand for food needs is related to the motivation of parents toward children to eat, while the responsiveness dimension is more about how parents pay attention to their children's interest in food, making children eat because of sensory aspects of food, such as appearance, taste, and smell of food [31]. The previous study among Norwegian mothers showed that reported eating disorder was affected by feeding style [32].

\section{Self-efficacy}

The ability of caregivers to take care of the children with ARFID in increasing self-efficacy has also changed better. This is shown by the mother's behavior in identifying her own weaknesses and strengths, increasing her ability to set goals, doing affirmations, and relax. Self-confidence in the ability of a mother to overcome ARFID problems in children is an important asset in solving ARFID cases in family. Strong selfefficacy will encourage mothers to take care of their children properly. Moreover, it will maintain mother's motivation, realistic goals, and emotions. Self-efficacy is the belief to succeed in carrying out behaviors that lead to the desired results [33], [34]. Self-efficacy defines the personal confidence or ability to act. Furthermore, self-efficacy is a personal belief in his ability to carry out a special task or part of the various components of the task. High self-efficacy will achieve a better performance because the individual has strong motivation, clear goals, stable emotions, and the ability to perform a successful activity or behavior [35]. The previous study showed that self-efficacy decreased the eating behavior [36], [37], [38].

\section{Conclusion}

Based on the results of the study, it can be concluded that the learning module program on the mothers' ability to take care of children with ARFID could improve the ability to adapt to new foods to children, adopt better eating patterns, and increase self-efficacy.
The learning module program on the ability to take care of children with ARFID could be recommended as an intervention in the field of community nursing that focuses on improving nutrition on the children with ARFID.

\section{Acknowledgment}

We would like to acknowledge the Health Sciences Faculty, Muhammadiyah University of Malang, for the assistance in undertaking this research. We would also like to express our gratitude to the study participants, data collectors, and supervisors.

\section{References}

1. Alberts Z, Fewtrell M, Nicholls DE, Biassoni L, Easty $M$, Hudson LD. Bone mineral density in anorexia nervosa versus avoidant restrictive food intake disorder. Bone. 2020;134:115307. https://doi.org/10.1016/j.bone.2020.115307

PMid:32142910

2. Ma R, Capobianco KP, Buchanan NC, Hu Z, Oakman JM Etiologic and treatment conceptualizations of disordered eating symptoms among mainland Chinese therapists. Int J Eat Disord. 2020;53(3):391-403. https://doi.org/10.1002/eat.23204

3. Sharp WG, Volkert VM, Scahill L, Mccracken CE, Mcelhanon B. A systematic review and meta-analysis of intensive multidisciplinary intervention for pediatric feeding disorders: How standard is the standard of care? J Pediatr. 2016;181:116-24.e4. https://doi.org/10.1016/j.jpeds.2016.10.002

PMid:27843007

4. Feillet $F$, Bocquet $A$, Briend $A$, Chouraqui JP, Darmaun D, Frelut ML, et al. Nutritional risks of ARFID (avoidant restrictive food intake disorders) and related behavior. Arch Pédiatr. 2019;26(7):437-41. https://doi.org/10.1016/j. arcped.2019.08.005 PMid:31500920

5. Jansen E, Harris H, Daniels L, Thorpe K, Rossi T. Acceptability and accessibility of child nutrition interventions: Fathers' perspectives from survey and interview studies. Int $\mathrm{J}$ Behav Nutr Phys Act. 2018;15(1):1-12. https://doi.org/10.1186/ s12966-018-0702-4

6. Bekelman TA, Bellows LL, Johnson SL. Are family routines modifiable determinants of preschool children's eating, dietary intake, and growth? A review of intervention studies. Curr Nutr Rep. 2017;6(2):171-89. https://doi.org/10.1007/ s13668-017-0207-9

7. Prasetyo YB, Kurnia AD, Masruroh NL, Nursalam N, Hargono R, Ahsan A, et al. Factors influencing promotive behaviours in mothers of Indonesian children with avoidant restrictive food intake disorder. J Taibah Univ Med Sci. 2019;14(5):454-9. https://doi.org/10.1016/j.jtumed.2019.07.003 PMid:31728144

8. Ulfiana E, Rachmawati PD, Fadhilah DK. Contributing factors of the mother's behavior in fulfilling nutritional needs for under-five children with overweight and obesity. Indian J Public Health Res Dev. 2019;10(8):2713-8. https://doi. 


\section{org/10.5958/0976-5506.2019.02280.0}

9. Bader LR, Fouts HN, Jaekel J. Mothers' feelings about infants negative emotions and mother-infant interactions among the Gamo of Southern Ethiopia. Infant Behav Dev. 2019;54:22-36. https://doi.org/10.1016/j.infbeh.2018.09.005 PMid:30522050

10. Dovey TM, Kumari V, Blissett J. Eating behaviour, behavioural problems and sensory profiles of children with avoidant/ restrictive food intake disorder (ARFID), autistic spectrum disorders or picky eating: Same or different? Eur Psychiatry. 2019;61:56-62. https://doi.org/10.1016/j.eurpsy.2019.06.008 PMid:31310945

11. Walton K, Kuczynski L, Haycraft E, Breen A, Haines J. Time to re-think picky eating ?: A relational approach to understanding picky eating. Int J Behav Nutr. 2017;14(1):62. https://doi. org/10.1186/s12966-017-0520-0 PMid:28476160

12. Van Der Geest KE, Mérelle SY, Rodenburg G, Van De Mheen D, Renders CM. Cross-sectional associations between maternal parenting styles, physical activity and screen sedentary time in children. BMC Public Health. 2017;17(753):1-10. https://doi. org/10.1186/s12889-017-4784-8 PMid:28962600

13. Pike KM, Dunne PE. The rise of eating disorders in Asia: A review. J Eat Disord. 2015;3(1):33. https://doi.org/10.1186/ s40337-015-0070-2 PMid:26388993

14. Noe F, Kusuma FH, Rahayu W. Hubungan tingkat stres dengan eating disorder pada mahasiswa yang tinggal di asrama putri UNITRI. Nurs News (Meriden). 2019;4(1):159-70.

15. Sharma N, Gupta M, Aggarwal AK, Gorle M. Effectiveness of a culturally appropriate nutrition educational intervention delivered through health services to improve growth and complementary feeding of infants : A quasi-experimental study from Chandigarh, India. PLoS One. 2020;15(3):1-22. https://doi. org/10.1371/journal.pone.0229755

PMid:32182241

16. Naim R, Juniarti N, Yamin A. Pengaruh edukasi berbasis keluarga terhadap intensi ibu hamil untuk optimalisasi nutrisi pada 1000 hari pertama Kehidupan. J Keperawatan Padjadjaran. 2017;5(2):185-96. https://doi.org/10.24198/jkp. v5i2.475

17. Indriyani D, Asih SW. Family-based maternal sensitivity model as a strategy to optimize family perception on the role of parents and the growth of infants. J Ners. 2018;13(1):17. https://doi. org/10.20473/jn.v13i1.5690

18. Mediarti D, Rosnani R, Sukartini T, Arifin H, Kurniawati $Y$, Coverage and factors associated with complete polio vaccination among Indonesian children aged 0-18 months. Child Youth Serv Rev. 2020;118:105399. https://doi.org/10.1016/j. childyouth.2020.105399

19. Gomes $\mathrm{Al}$, Barros L, Pereira $\mathrm{Al}$, So $\mathrm{M}$, Mendonça $\mathrm{M}$. Assessing children's willingness to try new foods: Validation of a portuguese version of the child's food neophobia scale for parents of young children. Food Qual Prefer. 2018;63:151-8. https://doi.org/10.1016/j.foodqual.2017.11.008

20. Moding KJ, Bellows LL, Grimm KJ, Johnson SL. A longitudinal examination of the role of sensory exploratory behaviors in young children's acceptance of new foods. Physiol Behav. 2020;218:112821. https://doi.org/10.1016/j. physbeh.2020.112821 PMid:32001305

21. Houston-Price C, Owen LH, Kennedy OB, Hill C. Parents experiences of introducing toddlers to fruits and vegetables through repeated exposure, with and without prior visual familiarization to foods: Evidence from daily diaries. Food
Qual Prefer. 2019;71:291-300. https://doi.org/10.1016/j. foodqual.2018.08.003

22. Kutbi HA, Alhatmi AA, Alsulami MH, Alghamdi SS, Albagar SM, Mumena WA, et al. Food neophobia and pickiness among children and associations with socioenvironmental and cognitive factors. Appetite. 2019;142:104373. https://doi.org/10.1016/j. appet.2019.104373 PMid:31325473

23. Maiz E, Urkia I, Bereciartu A, Urdaneta E, Allirot X. Introducing novel fruits and vegetables: Effects of involving children in artistic plating of food. Food Qual Prefer. 2019;77:172-83. https://doi.org/10.1016/j.foodqual.2019.05.006

24. Astuti ES, Nursalam N, Devy SR, Etika R. Mother's independence model within caring for low birth weight babies at home after hospital care based on mother factors, family support, and social support. Indian J Public Heal Res Dev. 2019;10(10):1685. https://doi.org/10.5958/0976-5506.2019.03085.7

25. Hassan R, Mills AS, Day KL, Van Lieshout RJ, Schmidt LA. Relations among temperament, familial socioeconomic status, and inhibitory control in typically developing four-year-old children. J Child Fam Stud. 2019;28(4):950-8. https://doi. org/10.1007/s10826-019-01329-4

26. Wang Y, Min J, Harris K, Khuri J, Anderson LM. A Systematic Examination of Food Intake and Adaptation to the Food Environment by Refugees Settled in the United States. Adv Nutr An Int Rev J. 2016;7(6):1066-79. https://doi.org/10.3945/ an.115.011452 PMid:28140324

27. Tetra Dewi FS, Stenlund $H$, Marlinawati VU, Öhman $A$, Weinehall L. A community intervention for behaviour modification: An experience to control cardiovascular diseases in Yogyakarta, Indonesia. BMC Public Health. 2013;13(1):1043. https://doi.org/10.1186/1471-2458-13-1043

PMid:24188684

28. Graziano PA, Bagner DM, Slavec J, Hungerford G, Kent K, Babinski D, et al. Feasibility of intensive parent-child interaction therapy (I-PCIT): Results from an open trial. J Psychopathol Behav Assess. 2015;37(1):38-49. https://doi.org/10.1007/ s10862-014-9435-0

PMid:26097286

29. Kusnanto K, Kurniawati ND, Bakar A, Wahyuni ED, Arifin H, Pradipta RO. Spiritual-based motivational self-diabetic management on the self-efficacy, self-care, and $\mathrm{HbA} 1 \mathrm{c}$ of Type 2 diabetes mellitus. Syst Rev Pharm. 2020;11(7):304-8.

30. Sjarif DR, Yuliarti K, Wahyuni LK, Wiguna T, Prawitasari T, Devaera $Y$, et al. Effectiveness of a comprehensive integrated module using interactive lectures and workshops in understanding and knowledge retention about infant feeding practice in fifth year medical students: A quasi-experimental study. BMC Med Educ. 2016;16(1):210. https://doi.org/10.1186/ s12909-016-0705-2

PMid:27538528

31. van der Horst K, Sleddens EF. Parenting styles, feeding styles and food-related parenting practices in relation to toddlers' eating styles: A cluster-analytic approach. PLoS One. 2017;12(5):e0178149. https://doi.org/10.1371/journal. pone. 0178149

PMid:28542555

32. Reba-Harrelson L, Von Holle A, Hamer RM, Torgersen L, Reichborn-Kjennerud T, Bulik CM. Patterns of maternal feeding and child eating associated with eating disorders in the Norwegian Mother and Child Cohort Study (MoBa). Eat Behav. 2010;11(1):54-61. https://doi.org/10.1016/j.eatbeh.2009.09.004 PMid:19962121

33. Dawson L, Mullan B, Sainsbury K. Using the theory of planned behaviour to measure motivation for recovery in anorexia 
nervosa. Appetite. 2015;84:309-15. https://doi.org/10.1016/j. appet.2014.10.028

\section{PMid:25450891}

34. Colditz P, Sanders MR, Boyd R, Pritchard M, Gray P, O'Callaghan $\mathrm{MJ}$, et al. Prem baby triple $\mathrm{P}$ : A randomised controlled trial of enhanced parenting capacity to improve developmental outcomes in preterm infants. BMC Pediatr. 2015;15(1):15. https://doi.org/10.1186/s12887-015-0331-x PMid:25884634

35. Trilolita V, Siti AE, Cahyo M. Pengaruh self-efficacy terhadap employee engagement dan kinerja karyawan (studi pada Karyawan PT Telekomunikasi Indonesia Regional V Surabaya). J Adm Bisnis. 2009;52(1):6234. https://doi.org/10.29303/jseh. v5i2.63

36. Czarlinski JA, Aase DM, Jason LA. Eating disorders, normative eating self-efficacy and body image self-efficacy: Women in recovery homes. Eur Eat Disord Rev. 2012;20(3):190-5. https:// doi.org/10.1002/erv.1116

PMid:21751298

37. Dzielska A, Mazur J, Nałęcz H, Oblacińska A, Fijałkowska A Importance of self-efficacy in eating behavior and physical activity change of overweight and non-overweight adolescent girls participating in healthy me: A lifestyle intervention with mobile technology. Nutrients. 2020;12(7):2128. https://doi. org/10.3390/nu12072128

PMid:32709005

38. Glasofer DR, Haaga DA, Hannallah L, Field SE, Kozlosky M, Reynolds J, et al. Self-efficacy beliefs and eating behavior in adolescent girls at-risk for excess weight gain and binge eating disorder. Int J Eat Disord. 2013;46(7):663-8. https://doi. org/10.1002/eat.22160

PMid:23881587 